\title{
A PROSPECTIVE RANDOMISED CLINICAL TRIAL OF THREE DIFFERENT DOSES OF ROCURONIUM FOR INTUBATION IN ADULTS
}

\author{
L. Raghavan', Gnanaganesh Venkatesan'2, K. R. Padmanabhan ${ }^{3}$
}

\author{
${ }^{1}$ Associate Professor, Department of Anaesthesiology, Chengalpattu Medical College, Affiliated to Tamilnadu Dr. MGR Medical \\ University, Chengalpattu, Chennai. \\ ${ }^{2}$ Assistant Professor, Department of Anaesthesiology, Chengalpattu Medical College, Affiliated to Tamilnadu Dr. MGR Medical \\ University, Chengalpattu, Chennai. \\ ${ }^{3}$ Assistant Professor, Department of Anaesthesiology, Chengalpattu Medical College, Affiliated to Tamilnadu Dr. MGR Medical \\ University, Chengalpattu, Chennai.
}

\section{ABSTRACT}

\section{BACKGROUND}

In the triad of anaesthesia, reflex suppression and facilitation of tracheal intubation is achieved by administering neuromuscular blocking agents. An ideal muscle relaxant should have rapid onset, profound muscle relaxation and short duration of action, so that patient's own respiratory function can be restored should intubation prove to be impossible. Succinylcholine is a depolarising muscle relaxant with a rapid onset of action, but associated with multiple side effects. Therefore, need exists for a non-depolarising muscle relaxant with a rapid onset of action without significant side effects. Rocuronium bromide is a steroidal non-depolarising neuromuscular blocking agent shown to have rapid onset of action similar to succinylcholine. ${ }^{1}$

This study was done to compare intubating conditions in 60 seconds by using three different doses of rocuronium for intubation in adults by assessing the onset and duration of neuromuscular blockade, intubating conditions and haemodynamic changes.

\section{MATERIALS AND METHODS}

Sixty patients of either sex of ASA grade 1 and 2, in the age group of 25 to 45 were randomly divided into three groups of 20 each. Group 1, 2 and 3 received rocuronium $0.6 \mathrm{mg} / \mathrm{kg}, 0.9 \mathrm{mg} / \mathrm{kg}$ and $1.2 \mathrm{mg} / \mathrm{kg}$ respectively for intubation.

Statistical Analysis - All recorded data were entered using MS Excel software and analysed using STATA software for determining the statistical significance. Analysis of Variance (ANOVA) was used to study the significance of mean of various study parameters among the three groups. Student's ' $t$ ' test was used to compare the two groups on mean values of various parameters. A value of $\mathrm{P}<$ 0.05 is considered as significant.

\section{RESULTS}

There was no statistically significant difference with regard to onset time and intubating conditions between doses of $0.9 \mathrm{mg} / \mathrm{kg}$ (Group 2) and $1.2 \mathrm{mg} / \mathrm{kg}$ (Group 3). All the patients in Group 2 and Group 3 achieved ideal intubating conditions (excellent + good), while it was only $45 \%$ in Group 1 . The duration of action of rocuronium was also prolonged in Group 3.

\section{CONCLUSION}

From the above study, by assessing the parameters like onset time, duration of neuromuscular blockade, intubating conditions and haemodynamic changes, we conclude that rocuronium in the dose of $0.9 \mathrm{mg} / \mathrm{kg}$ (Group 2) is faster and an ideal dose for intubation than the other two groups.

\section{KEYWORDS}

Rocuronium, Intubating Conditions, Jaw Relaxation.

HOW TO CITE THIS ARTICLE: Raghavan L, Venkatesan G, Padmanabhan KR. A prospective randomised clinical trial of three different doses of rocuronium for intubation in adults. J. Evolution Med. Dent. Sci. 2016;5(88):6560-6564, DOI: $10.14260 / \mathrm{Jemds} / 2016 / 1483$

\section{BACKGROUND}

Succinylcholine is a depolarising muscle relaxant available for rapid tracheal intubation. ${ }^{2}$ Its use is associated with complications like bradycardia, ${ }^{3}$ hyperkalemia, ${ }^{4}$ raised intraocular pressure, ${ }^{5}$ myalgia, ${ }^{6}$ etc.

Financial or Other, Competing Interest: None.

Submission 28-09-2016, Peer Review 22-10-2016,

Acceptance 28-10-2016, Published 02-11-2016.

Corresponding Author:

Dr. L. Raghavan,

A-40, Arcot Terrace,

No.160-NSK Salai,

Vadapalani,

Chennai - 600026.

E-mail: Iraghavan63@gmail.com

DOI: $10.14260 /$ jemds $/ 2016 / 1483$

\section{MATERIALS AND METHODS}

This study was conducted in Chengalpattu Medical College, Chengalpattu, during the period between April and August 2016. After obtaining Ethical Committee approval, 60 patients of either sex of ASA Grade 1 and 2, in the age group of 25 to 45 were randomised into three groups of twenty each.

Group 1: Received rocuronium $0.6 \mathrm{mg} / \mathrm{kg}$.

Group 2: Received rocuronium $0.9 \mathrm{mg} / \mathrm{kg}$.

Group 3: Received rocuronium $1.2 \mathrm{mg} / \mathrm{kg}$.

\section{Inclusion Criteria}

1. Patients of ASA Grade I and II of either sex.

2. MPC I and II.

3. Age group of 25 to 45 years.

4. Elective surgeries posted under GA. 


\section{Exclusion Criteria}

1. Known or anticipated difficult airways.

2. Patients with neuromuscular disease.

3. Drugs known to interact with neuromuscular blocking agents.

4. Renal or Hepatic disorder.

5. Known allergy to drugs.

6. Pregnant or breast feeding patients.

\section{Preoperative Evaluation}

Written informed consent was obtained from all the patients. Any significant history regarding medical illness, previous anaesthesia and surgery, medications and allergy were recorded.

Complete physical examination and airway assessment was done. Routine laboratory investigations like $\mathrm{Hb} \%$, platelets, blood urea and sugar, serum creatinine, liver function tests, urine albumin and sugar, chest x-ray and ECG were done.

\section{Premedication}

All patients received Inj. pentazocine $0.5 \mathrm{mg} / \mathrm{kg}$ and Inj. glycopyrrolate $10 \mu \mathrm{g} / \mathrm{kg}$ IM 45 minutes prior to surgery.

\section{Induction of Anaesthesia}

After shifting the patient to operation theatre, intravenous line was secured using 18G cannula and maintenance intravenous fluids were started and baseline measurements of heart rate and blood pressure were recorded.

\section{Neuromuscular Monitor}

For stimulation of the ulnar nerve, the distal electrode was placed about $1 \mathrm{~cm}$ proximal to the point at which the proximal flexion crease of the wrist crosses the radial side of the tendon to the flexor carpi ulnaris muscle. The proximal electrode was placed $2-5 \mathrm{~cm}$ proximal to the distal electrode. Placement of negative electrode distally elicits the greatest neuromuscular response. ${ }^{7}$ With this placement of electrodes, electrical stimulation normally elicits only finger flexion and thumb adduction.

The patients were preoxygenated for 3 minutes and then induced with Inj. Thiopentone $5 \mathrm{mg} / \mathrm{kg}$ as a $2.5 \%$ solution given over 15 seconds. Following loss of consciousness, the ulnar nerve was stimulated at the wrist using peripheral nerve stimulator. The response to single twitch at $1.0 \mathrm{~Hz}$ was elicited and the current strength was progressively increased till the maximal thumb adduction was obtained. The current strength was noted and one and a half times the strength was used for elicitation of train of four stimuli.

A bolus IV dose of Inj. Rocuronium $0.6 \mathrm{mg} / \mathrm{kg}$ or $0.9 \mathrm{mg} / \mathrm{kg}$ or $1.2 \mathrm{mg} / \mathrm{kg}$ depending on the group was given over 5 seconds. Ventilation was first assisted and then controlled with $100 \%$ oxygen. TOF was elicited every 10 seconds. The trachea was intubated after 60 seconds. Intubation was performed by an experienced anaesthetist who was blinded to the study group. The conditions of intubation were evaluated and scored according to the scoring system described by Cooper et al. ${ }^{8}$

Onset time was taken as the time from the end of injection of the relaxant to the time when all four responses of TOF were abolished.

Pulse rate and mean blood pressure were recorded at 1 min., 3 mins. and 5 mins. after intubation. Anaesthesia was maintained with $33 \%$ oxygen and $66 \%$ nitrous oxide using closed circuit system with controlled ventilation and surgery was allowed to proceed. Neuromuscular function was monitored using TOF stimuli every 5 mins. The interval between the administration of the bolus dose of the relaxant and the reappearance of the two responses to TOF was taken as the duration of action.

\section{Observations}

\section{The following Observations were Recorded}

1. The mean onset time and duration of action of rocuronium.

2. The heart rate and mean arterial pressure were recorded before induction, during intubation and 1 minute, 3 minutes and 5 minutes after intubation.

3. Intubating conditions were scored by a scoring system used by Cooper et al (Table 1 and 2). The scores for jaw relaxation, vocal cord position and response to intubation were recorded on a four point scale (0-3).

\begin{tabular}{|c|c|c|c|}
\hline Score & $\begin{array}{c}\text { Jaw } \\
\text { Relaxation }\end{array}$ & $\begin{array}{c}\text { Vocal } \\
\text { Cords }\end{array}$ & $\begin{array}{c}\text { Response to } \\
\text { Intubation }\end{array}$ \\
\hline $\mathbf{0}$ & $\begin{array}{c}\text { Poor } \\
\text { (Impossible) }\end{array}$ & Closed & $\begin{array}{c}\text { Severe coughing or } \\
\text { bucking }\end{array}$ \\
\hline $\mathbf{1}$ & $\begin{array}{c}\text { Minimal } \\
\text { (Difficult) }\end{array}$ & Closing & Mild coughing \\
\hline $\mathbf{2}$ & $\begin{array}{c}\text { Moderate } \\
\text { (Fair) }\end{array}$ & Moving & $\begin{array}{c}\text { Slight } \\
\text { diaphragmatic } \\
\text { movement }\end{array}$ \\
\hline $\mathbf{3}$ & Good (Easy) & Open & None \\
\hline \multicolumn{3}{|c|}{ Table 1. Scoring of Intubating Conditions } \\
\hline
\end{tabular}

4. The scores obtained from the above parameters were used to grade the intubating condition of every patient.

\begin{tabular}{|c|c|}
\hline Intubating Conditions & Score \\
\hline Excellent & $8-9$ \\
\hline Good & $6-7$ \\
\hline Fair & $3-5$ \\
\hline Poor & $0-2$ \\
\hline Table 2. Grading of Intubating Conditions \\
\hline
\end{tabular}

\section{Statistical Analysis}

All recorded data were entered using MS Excel software and analysed using STATA software for determining the statistical significance. Analysis of Variance (ANOVA) was used to study the significance of mean of various study parameters among the three groups. Student's ' $t$ ' test was used to compare the two groups on mean values of various parameters. A value of $\mathrm{P}<$ 0.05 is considered as significant.

\section{RESULTS}

\begin{tabular}{|c|c|c|c|c|c|}
\hline & Impossible to Open & Open with Difficulty & Moderate Opening & Easy Opening & Mean \pm SD \\
\hline Group 1 & 1 & 6 & 11 & 2 & $1.7 \pm 0.7$ \\
\hline Group 2 & 0 & 0 & 6 & 14 & $2.7 \pm 0.5$ \\
\hline Group 3 & 0 & 0 & 6 & 14 & $2.7 \pm 0.5$ \\
\hline \multicolumn{7}{|c|}{ Table 3. Jaw Relaxation } \\
\hline
\end{tabular}




\begin{tabular}{|l|c|c|c|c|c|}
\hline & Closed & Closing & Moving & Open & Mean \pm SD \\
\hline Group 1 & 3 & 7 & 7 & 3 & $1.5 \pm 0.9$ \\
\hline Group 2 & 0 & 1 & 5 & 14 & $2.65 \pm 0.6$ \\
\hline Group 3 & 0 & 1 & 4 & 15 & $2.7 \pm 0.6$ \\
\hline \multicolumn{6}{|c|}{ Table 4. Vocal Cord Position } \\
\hline
\end{tabular}

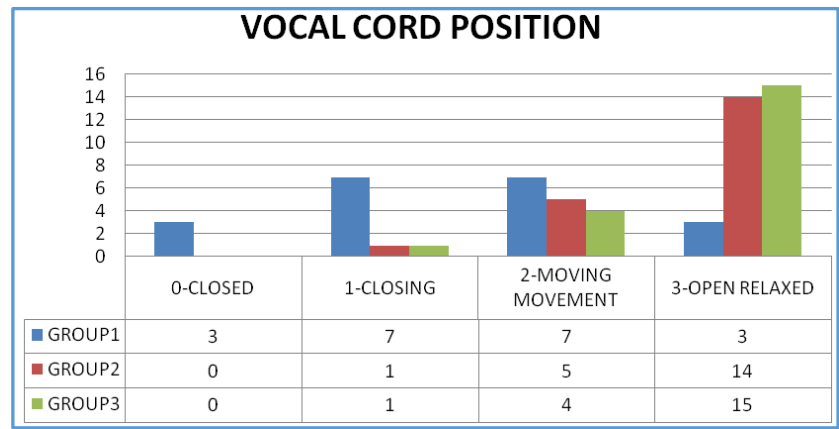

Figure 1

\begin{tabular}{|c|c|c|c|c|c|}
\hline & ن & 串 & 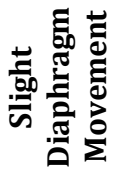 & 之苞 & 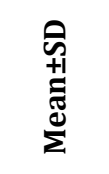 \\
\hline Group 1 & 2 & 7 & 9 & 2 & $1.6 \pm 0.8$ \\
\hline Group 2 & 0 & 0 & 5 & 15 & $2.8 \pm 0.4$ \\
\hline Group 3 & 0 & 0 & 4 & 16 & $2.8 \pm 0.4$ \\
\hline
\end{tabular}

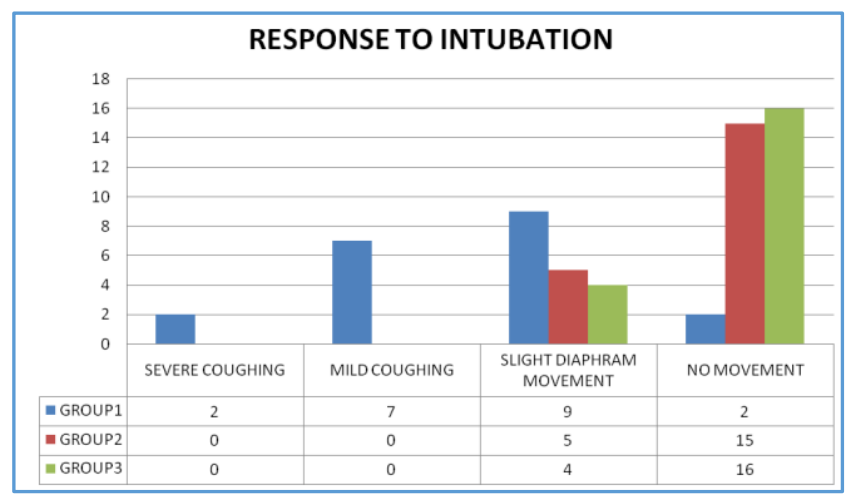

Figure 2. Response to Intubation

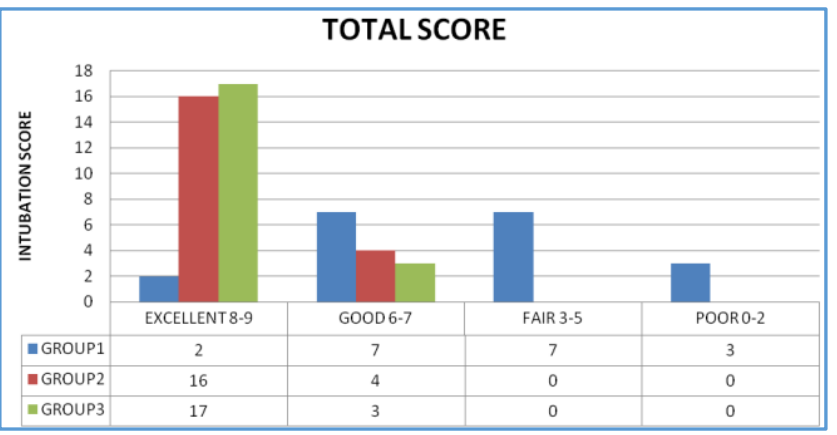

Figure 3. Grading of Intubating Condition

\begin{tabular}{|c|c|c|c|c|}
\hline Time & Group 1 & Group 2 & Group 3 & $\begin{array}{c}\text { P } \\
\text { value }\end{array}$ \\
\hline \multirow{2}{*}{ Baseline } & $90.3 \pm 10.3$ & $90.2 \pm 11.3$ & $90.15 \pm 9.9$ & $>0.05$ \\
& $(70-108)$ & $(76-120)$ & $(76-110)$ & \\
\hline \multirow{2}{*}{ Induction } & $\begin{array}{c}94 \pm 9.1(76- \\
112)\end{array}$ & $\begin{array}{c}93 \pm 11.9 \\
(80-126)\end{array}$ & $\begin{array}{c}94.3 \pm 9.7 \\
(80-112)\end{array}$ & $>0.05$ \\
\hline
\end{tabular}

\begin{tabular}{|c|c|c|c|c|}
\hline Intubation & $\begin{array}{c}108 \pm 11(90- \\
126)\end{array}$ & $\begin{array}{c}96.4 \pm 12.9 \\
(82-128)\end{array}$ & $\begin{array}{c}99.15 \pm 10.3 \\
(84-120)\end{array}$ & $<0.05$ \\
\hline \multirow{2}{*}{1 MIN } & $\begin{array}{c}110 \pm 11.7 \\
(94-130)\end{array}$ & $\begin{array}{c}93.05 \pm 10.4 \\
(80-114)\end{array}$ & $\begin{array}{c}95.65 \pm 9.5 \\
(80-116)\end{array}$ & $<0.05$ \\
\hline \multirow{2}{*}{3 MINS } & $\begin{array}{c}108.25 \pm 12.6 \\
(90-136)\end{array}$ & $\begin{array}{c}90.5 \pm 11.2 \\
(78-119)\end{array}$ & $\begin{array}{c}90.3 \pm 8.7 \\
(80-110)\end{array}$ & $<0.05$ \\
\hline \multirow{2}{*}{5 MINS } & $\begin{array}{c}99.9 \pm 11.2 \\
(86-126)\end{array}$ & $\begin{array}{c}86.4 \pm 10.3 \\
(74-122)\end{array}$ & $\begin{array}{c}85.65 \pm 6.4 \\
(74-98)\end{array}$ & $<0.05$ \\
\hline \multicolumn{5}{|c|}{ Table 6. Heart Rate - Mean \pm SD } \\
\hline
\end{tabular}

\begin{tabular}{|c|c|c|c|c|}
\hline Variable & Group 1 & Group 2 & Group 3 & $\begin{array}{c}\text { P } \\
\text { value }\end{array}$ \\
\hline \multirow{2}{*}{ Baseline } & $\begin{array}{c}88.15 \pm 8.2 \\
(67-103)\end{array}$ & $\begin{array}{c}92.3 \pm 5.6 \\
(82-101)\end{array}$ & $\begin{array}{c}90.1 \pm 6.5 \\
(80-103)\end{array}$ & $>0.05$ \\
\hline \multirow{2}{*}{ Induction } & $\begin{array}{c}87.7 \pm 9.8 \\
(67-104)\end{array}$ & $\begin{array}{c}90.85 \pm 6.9 \\
(77-102)\end{array}$ & $\begin{array}{c}88.1 \pm 8.0 \\
(76-102)\end{array}$ & $>0.05$ \\
\hline \multirow{2}{*}{ Intubation } & $\begin{array}{c}98.45 \pm 12.1 \\
(72-126)\end{array}$ & $\begin{array}{c}92.4 \pm 6.9 \\
(77-103)\end{array}$ & $\begin{array}{c}92.45 \pm 6.0 \\
(77-103)\end{array}$ & $<0.05$ \\
\hline \multirow{2}{*}{1 MIN } & $\begin{array}{c}99.3 \pm 9.5 \\
(67-11)\end{array}$ & $\begin{array}{c}92.05 \pm 4.9 \\
(84-103)\end{array}$ & $\begin{array}{c}90.55 \pm 6.8 \\
(69-102)\end{array}$ & $<0.05$ \\
\hline \multirow{2}{*}{3 MINS } & $\begin{array}{c}97.25 \pm 9.7 \\
(62-109)\end{array}$ & $\begin{array}{c}89.55 \pm 7.8 \\
(66-103)\end{array}$ & $\begin{array}{c}89.25 \pm 4.2 \\
(79-99)\end{array}$ & $<0.05$ \\
\hline \multirow{2}{*}{5 MINS } & $\begin{array}{c}93.85 \pm 8.48 \\
(69-109)\end{array}$ & $\begin{array}{c}88.9 \pm 4.7 \\
(80-97)\end{array}$ & $\begin{array}{c}87.35 \pm 3.5 \\
(82-94)\end{array}$ & $<0.05$ \\
\hline \multicolumn{5}{|c|}{ Table 7. Mean Arterial Pressure - Mean \pm SD } \\
\hline
\end{tabular}

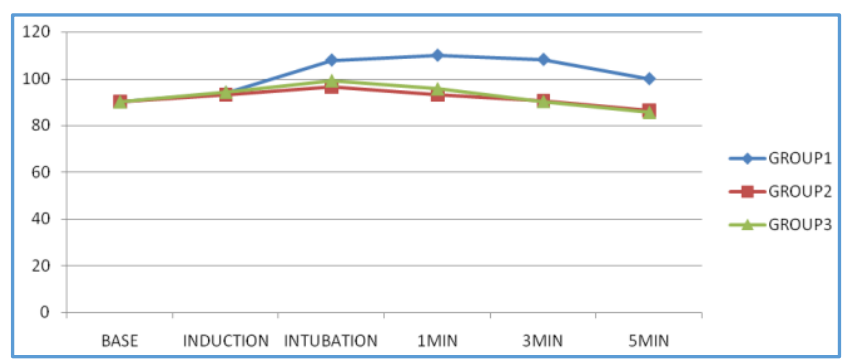

Figure 4. Distribution of Heart Rate Response

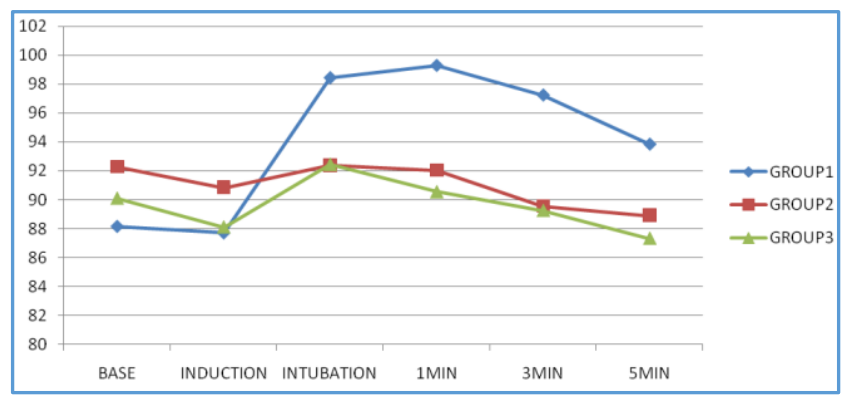

Figure 5. Distribution of Mean Arterial Pressure Response

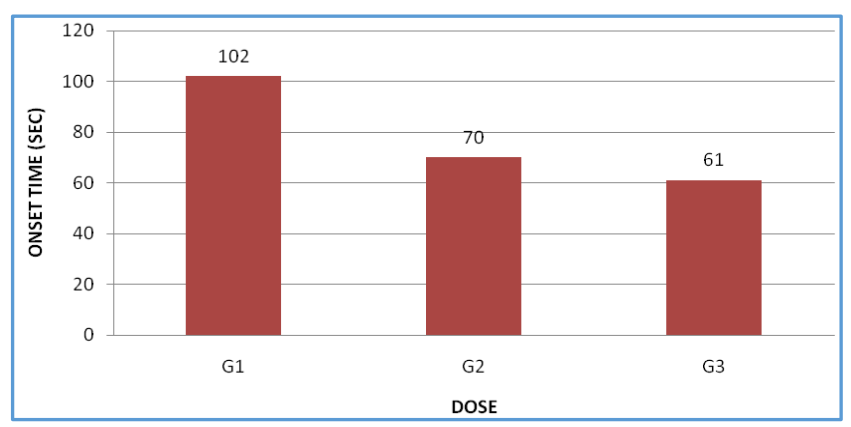

Figure 6. Mean Onset Time 


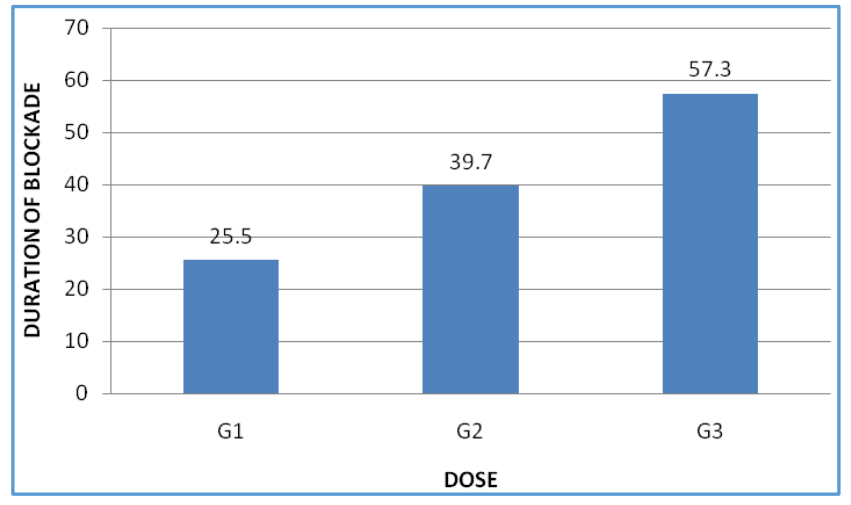

Figure 7. Mean Duration of Blockade

\section{DISCUSSION}

An ideal muscle relaxant should have non-depolarising mechanism of action, rapid onset, short duration, rapid recovery, non-cumulative, no histamine release, no cardiovascular side effects, high potency and prompt reversibility by cholinesterase inhibitors and pharmacologically inactive metabolites. Rocuronium, a nondepolarising neuromuscular blocker has the fastest onset time when compared to all other available non-depolarising neuromuscular blockers, having an onset time similar to succinylcholine. ${ }^{9}$

The duration of action of rocuronium (20 - 35 mins.) is similar to that of vecuronium and atracurium. Rocuronium is eliminated primarily by liver. 10

Unlike succinylcholine, rocuronium has little or no cardiovascular side effects ${ }^{11}$ and does not cause histamine release. ${ }^{12}$ Thus, it is ideal for rapid-sequence induction of anesthesia and may be preferable to succinylcholine in patients in whom cardiovascular effects are to be avoided.

The analysis of the results showed that the onset of blockade is inversely proportional to the dose of rocuronium. The onset time was significantly lower in Group 3 (61.2 \pm 12.95 seconds) and Group 2 (70 \pm 20.13 seconds) than in Group 1 (102.25 \pm 29.93 seconds). This is in accordance with Magorian $\mathrm{T}$ et $\mathrm{al},{ }^{13}$ who reported an onset time of 89 seconds with a dose of $0.6 \mathrm{mg} / \mathrm{kg}, 75$ seconds with $0.9 \mathrm{mg} / \mathrm{kg}$ and 55 secs. with 1.2 $\mathrm{mg} / \mathrm{kg}$. Naguib et $\mathrm{al}^{14}$ found that the onset time of rocuronium decreased from 97.9 seconds to 70.5 seconds as the dose increased from $0.6 \mathrm{mg} / \mathrm{kg}$ to $0.9 \mathrm{mg} / \mathrm{kg}$. One possible reason for rapid onset of block with rocuronium could be due to relatively low potency of the drug. This results in more number of molecules of the drug in the blood stream and subsequently in the neuromuscular junction.

The duration of neuromuscular blockade increases as the dose of rocuronium is increased. Duration of action was significantly higher in Group $3(57.25 \pm 7.51$ minutes) than in Group 2 (39.75 \pm 4.43 minutes) and Group 1 (25.5 \pm 3.95 minutes).

Naguib et al ${ }^{14}$ observed a duration of 36.4 minutes after a dose of $1 \mathrm{mg} / \mathrm{kg}$ of rocuronium. This is close to our observation of $39.75 \pm 4.43$ mins. with $0.9 \mathrm{mg} / \mathrm{kg}$ of rocuronium.

A clinical duration of $17.4 \pm 3.2$ mins. after $0.6 \mathrm{mg} / \mathrm{kg}$ rocuronium was reported by Booji et al,15 while we found duration of $25.5 \pm 3.59$ mins. after $0.6 \mathrm{mg} / \mathrm{kg}$ rocuronium.

De Mey J. C. et al ${ }^{16}$ found that the duration of action with $0.6 \mathrm{mg} / \mathrm{kg}$ was $27.3 \pm 8.2$ minutes with $0.75 \mathrm{mg} / \mathrm{kg}$ was $43.6 \pm 12.0$ minutes and $0.9 \mathrm{mg} / \mathrm{kg}$ was $53.0 \pm 15.2$ minutes.
Mayer et $\mathrm{al}^{17}$ reported a mean onset time of 1.8 minutes and clinical duration of action of 29 minutes following 0.6 $\mathrm{mg} / \mathrm{kg}$ of rocuronium.

On analysing the jaw relaxation, it was impossible to open the jaw in one case and we had minimal difficulty in six cases in Group 1, whereas these problems did not occur in Group 2 and Group 3. Statistical analysis showed that the mean score for jaw relaxation was significantly higher in Group 2 (2.7 \pm 0.47$)$ and Group $3(2.7 \pm 0.47)$ than Group $1(1.7 \pm 0.73)$.

Regarding vocal cord position the closed status (score 0 ) was seen in three cases in Group 1, whereas no such cases were encountered in Group 2 and Group 3. Mean score for vocal cord position was significantly higher in Group 2 $(2.65 \pm 0.58)$ and Group $3(2.7 \pm 0.57)$ when compared to Group $1(1.5 \pm 0.94)$.

With regard to response to intubation, two cases had severe coughing/bucking and seven cases had mild coughing in Group 1. These untoward events did not happen in Group 2 and Group 3. Mean score for response to intubation was significantly higher in Group $2(2.75 \pm 0.44)$ and Group 3 $(2.8 \pm 0.41)$ when compared to Group $1(1.55 \pm 0.82)$.

The analysis of intubation scores shows that higher doses result in a statistically significant increase in the ease of intubation. Mean total intubating score in Group $2(8.1 \pm 1.16)$ and Group $3(8.2 \pm 1.15)$ were significantly higher than Group 1 (4.75 \pm 2.19$)$.

In this study, acceptable intubating conditions (excellent and good scores) were observed in all the patients (100\%) in Group 2 and Group 3, but only in 9 patients (45\%) in Group 1. Jamshid Ali $^{18}$ et al concluded that intubating conditions after rocuronium $0.6 \mathrm{mg} / \mathrm{kg}$ at 60 secs. were not satisfactory in a significant number of cases. Therefore, they suggested that higher doses of rocuronium $(0.9-1.2 \mathrm{mg} / \mathrm{kg}$ ) should be used for rapid sequence induction of anaesthesia.

Cheng et al ${ }^{19}$ observed that rocuronium $0.9 \mathrm{mg} / \mathrm{kg}$ provides similar intubating conditions to suxamethonium 1.5 $\mathrm{mg} / \mathrm{kg}$, whereas rocuronium at $0.6 \mathrm{mg} / \mathrm{kg}$ was inadequate.

Statistical analysis revealed that there was no statistically significant difference with regard to mean heart rate and mean arterial pressure during intubation, whereas at 1, 3 and 5 minutes after intubation these variables were significantly higher in Group 1 than in Group 2 and Group 3.

Patients receiving $0.6 \mathrm{mg} / \mathrm{kg}$ were more likely to experience moderate coughing and bucking after tracheal tube insertion. Both $0.9 \mathrm{mg} / \mathrm{kg}$ and $1.2 \mathrm{mg} / \mathrm{kg}$ produce similar onset time and intubating conditions with no statistically significant difference between the two groups. Rocuronium in doses of $1.2 \mathrm{mg} / \mathrm{kg}$ produces similar intubating conditions as 0.9 $\mathrm{mg} / \mathrm{kg}$, but the duration of action is very much prolonged. No further improvement in intubation conditions were achieved by increasing the dose of rocuronium from $0.9 \mathrm{mg} / \mathrm{kg}$ to 1.2 $\mathrm{mg} / \mathrm{kg}$.

\section{CONCLUSION}

From the above study by assessing the parameters like onset time, duration of neuromuscular blockade, intubating conditions and haemodynamic changes, we conclude that rocuronium in the dose of $0.9 \mathrm{mg} / \mathrm{kg}$ (Group 2) produces ideal intubating conditions at a lower cost and is adequate for endotracheal intubation in adults. 


\section{REFERENCES}

1. Alvarez-Gomez JA, Estelles ME, Fabregat J, et al. Pharmacokinetics and pharmacodynamics of rocuronium bromide in adult patients. Eur J Anaesthesiol 1994;9:536.

2. Chestnut RJ, Healy TE, Harper NJ, et al. Suxamethonium the relationship between dose and response. Anaesthesia 1989;44(1):14-8.

3. Stoelting RK, Peterson C. Heart-rate slowing and junctional rhythm following intravenous succinylcholine with and without intramuscular atropine preanaesthetic medication. Anaesth Analg 1975;54(6):705-9.

4. Gronert GA, Theye RA. Pathophysiology of hyperkalemia induced by succinylcholine. Anaesthesiology 1975;43(1): 89-99.

5. Pandey K, Badola RP, Kumar S. Time course of intraocular hypertension produced by suxamethonium. Br J Anaesth 1972;44(2):191-6.

6. Waters DJ, Mapleson WW. Suxamethonium pains: hypothesis and observation. Anaesthesia 1971;26(2): 127-41.

7. Brull SJ, Silverman DG. Pulse width, stimulus intensity, electrode placement and polarity during assessment of neuromuscular block. Anaesthesiology 1995;83(4): 702-9.

8. Cooper R, Mirakhur RK, Clarke RS, et al. Comparison of intubating conditions after administration of org 9426 and suxamethonium. Br J Anaesth 1992;69(3):269-73.

9. Agoston S. Onset time and evaluation of intubating conditions: rocuronium in perspective. Eur J Anaesthesiol suppl 1995;11:31-7.

10. Proost JH, Roggerveld J, Wierda JM, et al. Relationship between chemical structure and physicochemical properties of series of bulky organic cations and their hepatic uptake and biliary excretion rates. J Pharmacol Exp Ther 1997;282(2):715-26.
11. McCoy EP, Maddineni VR, Elliot P, et al. Haemodynaemic effects of rocuronium during fentanyl anaesthesia: comparison with vecuronium. Can J Anaesth 1993;40(8): 703-8.

12. Naguib M, Samarkandi AH, Bakhamees HS, et al. Histamine-release and heamodynamic changes produced by rocuronium, vecuronium, mivacurium, atracurium and tubocurarine. Br J Anaesth 1995;75(5):588-92.

13. Magorian T, Flannery KB, Miller RD. Comparison of rocuronium, succinylcholine and vecuronium for rapid sequence induction of anaesthesia in adult patients. Anaesthesiology 1993;79(5):913-8.

14. Naguib M, Samarkandi AH, Ammar A, et al. Comparison of suxamethonium and different combinations of rocuronium and mivacurium for rapid tracheal intubation in children. Br J Anaesth 1997;79(4):450-5.

15. Booji LHDJ. A dose finding study with rocuronium bromide. Eur J Anaesthesiol 1994;11(Suppl 9):16-9.

16. De Mey JC, Debrock M, Rolly G. Evulation of the onset and intubating conditions of rocuronium bromide. European Journal Of Anaesthesiology 1994;9:37-40.

17. Mayer M, Doericke A, Hofmann A, et al. Onset and recovery of rocuronium (Org 9426) and vecuronium under enflurane anaesthesia. Br J anaesth 1992;69(5): 511-2.

18. Jamshid Ali, Gurckoo SA, Shora A, et al. Intubating conditions of rocuronium bromide and succinylcholine during rapid sequence induction of anaesthesia in unpremedicated adult patients. Journal of Anaesthesiology Clinical Pharmacology 2008;24(3):33742.

19. Fanzca C, Aun CS, Gin T. Comparison of rocuronium and suxamethonium for rapid tracheal intubation in children. Peadiatric Anaesthesia 2002;12(2):140-5. 